\title{
REVENUE SHARING REFORMULATION IN INDONESIA TAXATION: RESOLVING VERTICAL FISCAL INEQUALITY?
}

\author{
Soemiarsono B. ${ }^{*}$, Ananda C.F., Khusaini M., Susilo \\ Doctoral Program Economics, Faculty of Economics and Business, \\ University of Brawijaya, Indonesia \\ *E-mail: bobsmno@gmail.com
}

\begin{abstract}
Revenue Sharing Reformulation (RSR) serves to reduce Vertical Fiscal Imbalance (VFI). The current RSR Indonesia formula is still unable to reduce VFI, so there needs to be a RSR reformulation. This research uses quantitative approach method to measure VFI before and after RSR reformulation. RSR Reformulation was obtained through literature review, then simulation was performed. The results of this study indicate that RSR reformulation considering fiscal needs, fiscal capacity, and regional efforts. The variables used in the RSR reformulation are population, equal share, poverty, land area, fiscal responsibility, personal emolument factor, and development factor.
\end{abstract}

\section{KEY WORDS}

Share revenue, Vertical Fiscal Imbalance, policy, taxation, simulation.

Fiscal decentralization is expected to improve public services and encourage public sector efficiency, economic growth and community welfare (M. Khusaini, 2008). In the fiscal decentralization policy of the central government providing transfers to the regions, one component is tax revenue and non-tax revenue sharing $(\mathrm{DBH}) . \mathrm{DBH}$ is used as an instrument to reduce vertical fiscal imbalance aimed at balancing, equal distribution of income and level of public service between regions with varying economic capacity (Bird \& Tarasov, 2004).

However, in reality VFI Indonesia is still high. This is supported by research by Hamid (2005) and Shah \& Qureshi (1994). Kenworthy \& McCall (2008) argue that inequality can be caused by the unequal market mechanism and tax policies and unfair distribution. Then Hamid (2005) argues that vertical fiscal imbalances in Indonesia occur because the central government controls the main taxes, so that local controlled taxes are insufficient to fund local activities. Provision of development financing in the regions can impact on deteriorating regional services and disrupt regional and national stability (Bird \& Vaillancourt, 2000).

On the other hand, DBH mechanism still leaves various problems. These problems include the lack of attention to external cost components, especially DBH SDA (Saragih, 2011 in Kurniawati, 2012). Meanwhile, Kuncoro 2012 (in the Constitutional Court (2013) and Anom (2012)) suggests that in the legal process and the DBH mechanism is not based on academic and empirical considerations, only bargaining and political agreement. Therefore, there needs to be a revision related to these laws because it is "out of date" (Siddik, 2012 in the Constitutional Court, 2013 and Anom, 2012).

The weakness of transparency in data access and DBH calculation mechanism is also one of the problems in the implementation of DBH governance (Mustofa (2010), Khoirunurrofik, 2002). In fact, NRGI \& UNDP (2016) stated that local governments should be able to verify the value of revenues collected from mines and oil fields in their jurisdictions, thus encouraging trust among levels of government, or in some cases will ensure a strong peace. The transfer mechanisms that have been undertaken have not fully addressed development issues reflected in some macro indicators such as widening income gaps (Khusaini, 2014). Provinces that receive high DBH are mostly scattered in provinces that do have adequate natural resources such as East Kalimantan or National Industry supporters such as DKI, East Java and West Java. The relatively rich areas are developing faster than the relatively poor regions due to the good economic recovery program (World Bank, 2007). 
Based on the above explanation, this study aims to analyze the condition of vertical fiscal imbalances in Indonesia starting from differences in characteristics, resources and fiscal needs of each region in Indonesia. the reconstruction of the financial sector through revenue and expenditure policies at the government level is also required to minimize this imbalance.

\section{LITERATURE REVIEW}

Vertical Fiscal Imbalance. Vertial fiscal imbalance or Vertical Fiscal Imbalance (VFI) shows the difference in fiscal capacity and fiscal needs between central government and lower levels of government (Suyanto, 2017). Vertical fiscal inequality is closely linked to decentralized spending responsibilities with centralized funding (Ruggeri \& Howard, 2000). VIF occurs because of the distribution of revenue sources between the central and provincial governments that are inconsistent with the distribution of responsibility for expenditures (Anonymous, 2001).

According to Zuker (2002), VIF is a product of vertical political imbalance. Therefore, to reduce the occurrence of the case, the Commonwealth takes some of the functions of the State, but it faces political and legal obstacles (Webb, 2002). In addition, the distribution of revenue sources between central and local governments is inconsistent with the costs of meeting the constitutional spending responsibilities, resulting in poorer equity (Bird \& Tarasov, 2002). The view (Hilaire-St, 2005), which states that Vertical Fiscal Inequality (VFI) is the asymmetry of increasing revenue between the provincial government and the federal government, which in turn changes the view of optimal division of responsibilities among them.

The purpose of fiscal decentralization is the presence of vertical fiscal equity between central and autonomous governments. So that local government are able to perform public services more optimally. In fact, not a few areas earn public services whereas local government is the spearhead of service (Khusaini, 2016). To that end, the central government provides a portion of revenue derived from the region, redistributed to regions under certain laws and formulas (Langoday, 2006). Meanwhile, VFI emerges because of the disparity between capacity and fiscal needs between the central and regional levels. Karpowicz (2012) identifies VFI as an obstacle to regional accountability and better regional fiscal performance. Vertical fiscal imbalances occur when decentralization spends income for the region so that local governments must rely on transfer funds (Khusaini, 2017). Eyraud \& Lusinyan (2013) confirmed that the increase in fiscal imbalances is related to the weakening of the fiscal balance of the central government. This allows for increased deficits which often require balance funds. It is important to develop fiscal adjustment strategies, especially changes in intergovernmental relationships as part of fiscal reforms.

Fund Transfer Criteria. Intergovernmental fiscal transfers can basically be grouped as follows (Kustianto and Yansekardias, 2001):

1. Transfer allocation model that takes into account fiscal gap (fiscal gap);

2. Transfer allocation model based on fiscal capacity considerations between regions;

3. Transfer allocation models are based on various "needs" indicators;

4. Transfer allocation model based on equality of per capita tax base.

Meanwhile, Ananda (2002) mentions three basic ways of determining the amount of funds that need to be distributed to regions through intergovernmental fiscal transfers, namely: (a) by a fixed percentage of central government revenues; (b) adheres to an ad hoc basis, ie, in the same manner as for other types of budgetary expenditures; and (c) on the basis of a 'formula mechanism', ie, by a percentage of certain regional expenditures paid by the center, or in connection with some general characteristics of the receiving area.

According to Sidik et al. (2002) there are several criteria related to the design of central transfers to regions, namely autonomy, adequate income, equity, transparent and stable, simplicity and incentives. Accordingly, NRGI and UNDP (2016) state that the revenuesharing formula should be simple and enforceable, achieve national consensus on the formula, codify the formula in law, transparent and formalize independent oversight. The 
revenue-sharing formula should be simple, easy to implement in order to avoid complaints from the region. In addition, the formula prepared must be accepted by all parties including political groups and ethnic groups masyarakta and other stakeholders. Any revenue-sharing formula must be codified / formalized through other laws or regulations, this will increase certainty and the government and the public will get the strengths and weaknesses of the formula based on the public debate that took place. One thing that is important is that the revenue-sharing formula must be transparent and can be audited at any time and can be published to the public, this may lead to a higher level of confidence in the central government.

Meanwhile, Yilmaz (2003) conveyed that the criteria for intergovermental transfer system are, among others, the adequacy and buoyancy, predictability, simplicity and transparency of intergovernmental transfers, transfer system and its impact on allocative efficiency, interregional equity and incentive, structure for sound fiscal management and subnational resource mobilization. Yilmaz's thinking is in line with what Schroeder and Smoke (2002) suggest that the design criteria for transfer are: adequacy and growth; predictability, simplicity and transparency; allocative efficiency; equity (in terms of redistribution); and incentives for sound fiscal management and subnational resource mobilization.

Devas (2002) also conveyed that the transfer design must meet the minimum criteria of incentives, predictability, and transparency. The transfer formula should encourage efforts to increase local revenue, meaning that with increasing income, the greater the transfer received by the region. with the existence of transparency is expected to avoid political manipulation, negoisasi, and corruption. When earnings can be predicted more precisely then local governments will be more flexible and accurate in determining shopping activities. Meanwhile, according to Otieno, et.al. (2014), the criteria of transfer allocation among them are consistency, fairness, and transparency.Furthermore, Jun Ma (1997) stated that the effective transfer system must meet the criteria of adequacy of revenue, Local tax effort and expenditure control, equity, transparency and stability.

Based on the opinion of the experts above it appears that the criteria of a good design transfer formula must at least meet the elements such as revenue adequacy, equity, predictability, simplicity and transparency, and provide incentive for the region in encouraging efforts to increase local revenue.

\section{METHODS OF RESEARCH}

Analysis of Vertical Fiscal Imbalance. With reference to the model of Bird \& Tarasov (2002), the model of calculating the vertical fiscal imbalance is formulated as follows:

$$
\begin{aligned}
C V I_{1} & =\frac{\left(\text { Revenue }_{S H}\right)_{S N G}}{\left(\text { Expenditure }_{\text {Lending }}\right)_{S N G}} \\
C V I_{2} & =\frac{\left(\text { Revenue }_{S H}\right)_{S N G}+(I G N B)_{S N G}}{\left(\text { Expenditure }_{\text {Lending }}\right)_{S N G}} \\
C V I_{3} & =1-\left(\frac{\left(\text { Revenue }_{\text {Grants }}\right)_{S N G}-\left(\text { Revenue }_{S H}\right)_{S N G}-(I G N B)_{S N G}}{(\text { Expenditure }+ \text { Lending })_{S N G}}\right)
\end{aligned}
$$

Where:

CVII: share of government transfers to provincial government expenditures / spending;

CVIII: share of government transfers and local lending to provincial government expenditures / spending);

CVIII: Share provincial spending that is not discover by PAD province;

CVI: Vertical Imbalance Coefficient;

TRsp: Special Allocation Fund (DAK);

TRbp: General Allocation Fund (DAU);

B: Regional Loans;

EXP: Total Spending of APBD; 
IGNB: Reception of Loans;

REV: Regional Income;

REVSH: Profit Sharing (BHP) and Non-Tax Revenue (BHBP);

SNG: Sub National Government (Province).

According to Hamid (2005) and Shah \& Qureshi (1994) the magnitude of the vertical fiscal imbalance of a region can be seen based on the value of the fiscal coefficient coefficient of magnitude between 0 and 1 . The smaller the coefficient value, the higher fiscal imbalance that means that regions are increasingly dependent on the central government. On the contrary, the greater the coefficient of fiscal inequality shows the more independent of these regions in financing their expenditure.

To analyze the DBH reformulation, this study refers to the formulation of the Kenyan DBH Commission on Revenue Allocation (CRA) (2010). The formula used as follows:

$$
\mathrm{CA}_{\mathrm{it}}=\beta_{1}(\mathrm{PN})_{\mathrm{it}}+\beta_{2}(\mathrm{ES})_{\mathrm{it}}+\beta_{3}(\mathrm{PI})_{\mathrm{it}}+\beta_{4}(\mathrm{LA})_{\mathrm{it}}+\beta_{5}(\mathrm{FR})_{\mathrm{it}}+\beta_{6}(\mathrm{PE})_{\mathrm{it}}+\beta_{7}(\mathrm{DF})_{\mathrm{it}}
$$

Where: CAit $=$ Regional revenue share $\mathrm{i}$ at time $\mathrm{t} ; \beta 1-7=$ weighted value of independent variable 1-7; $\mathrm{PNit}=$ The population of region $\mathrm{i}$ at time $\mathrm{t}$; ESIT $=$ Local allocation fund $\mathrm{i}$ at time $\mathrm{t}$; Plit $=$ Local poverty rate $\mathrm{i}$ at time $\mathrm{t}$; LAIT $=$ Area of area $\mathrm{i}$ at time $\mathrm{t}$; FRit $=$ fiscal capacity area $\mathrm{i}$ at time $\mathrm{t}$; PEit $=$ Regional bureaucratic Reform Index $\mathrm{i}$ at time $\mathrm{t}$; DFit $=$ Regional economic growth i at time $t$.

DBH reformulation simulation for 3 (three) years, ie 2014-2015. DBH Reformulation is done on $\mathrm{DBH}$ allocation in 34 Provinces in Indonesia.

\section{RESULTS AND DISCUSSION}

Reformulation of Calculation Model of Allocation of Revenue Sharing Funds. Reformulation of DBH DBH Commission on Revenue Allocation (CRA) Kenya (2010). The formula consists of population, equal share, poverty, land area, fiscal responsibility, personal emolument factor, and development factor variables. In this study population in proxy with population, equal share in proxy with General Allocation Fund (DAU), poverty in proxy with poverty level, land area in proxy with province area, fiscal responsibility in proxy with fiscal capacity of area, personal emolument factor in proxies with reform index of bureaucracy, and development factor in proxies with regional economic growth.

By incorporating the weight of each indicator on the Kenyan DBH Commission on Revenue Allocation (CRA) formula (2010), the DBH formula used is as follows:

$$
\mathrm{CA}_{\mathrm{it}}=0.45(\mathrm{PN})_{\mathrm{it}}+0.25(\mathrm{ES})_{\mathrm{it}}+0.18(\mathrm{PI})_{\mathrm{it}}+0.08(\mathrm{LA})_{\mathrm{it}}+0.01(\mathrm{FR})_{\mathrm{it}}+0.02(\mathrm{PE})_{\mathrm{it}}+0.01(\mathrm{DF})_{\mathrm{it}}
$$

The results of the DBH reformulation simulations are shown in Tables 1-3. Based on tables it appears that most provinces in Indonesia have increased the allocation of DBH between $\mathrm{DBH}$ allocations prior to $\mathrm{DBH}$ reformulation and after $\mathrm{DBH}$ reformulation. Provinces with decreasing $\mathrm{DBH}$ allocations after $\mathrm{DBH}$ reformulation include DKI Jakarta, East Kalimantan, West Papua, Bengkulu, North Kalimantan and West Sulawesi provinces. This indicates that the allocation of DBH for this is greater than the fiscal needs.

Vertical Balance Coefficient Analysis. The coefficient of vertical imbalance becomes a statistical tool to test how the impact of the Revenue Sharing Fundamentals on vertical fiscal inequality (between the central government and the province). In table 4 and the figure below will show how the effect of an Opsen-based Revenue Sharing Fund is based on the coefficient vertical imbalance (CVI). CVI is divided into 3 categories that are tailored to the interpretation of the results the researcher wants. The following is a CVI of Opsen-based simulation based on the 2014-2016 databases. 
Table 1 - DBH Allocation after the Reformulation of 2014 (in Rp.)

\begin{tabular}{|c|c|c|}
\hline \multirow{2}{*}{ Province } & \multicolumn{2}{|c|}{2014} \\
\hline & PRE & POST \\
\hline Aceh & 243.817.733.171 & 432.785.116.183 \\
\hline Sumatera Utara & 384.866 .615 .036 & 1.104 .209 .489 .074 \\
\hline Sumatera Barat & 120.406 .149 .738 & 432.307 .976 .560 \\
\hline Riau & 741.712 .126 .770 & 811.274 .887 .906 \\
\hline Jambi & 214.378.292.652 & 320.311 .450 .520 \\
\hline Sumatera Selatan & 217.383 .227 .805 & 605.672 .270 .177 \\
\hline Bengkulu & 588. 115.602 .332 & 168.017 .025 .066 \\
\hline Lampung & 58.390 .026 .118 & 568.675 .253 .236 \\
\hline Kep. Bangka Belitung & 47.737.911.516 & 141.002 .981 .956 \\
\hline Kep. Rixu & 132.297 .043 .006 & 267.552 .985 .146 \\
\hline DKI Jakarta & 9.825 .434 .652 .218 & 7.818 .558 .625 .842 \\
\hline Jawa Barat & 1.041 .739 .075 .589 & 3.759 .560 .112 .644 \\
\hline Jawa Tengah & 421.254 .688 .102 & 2.479 .105 .578 .105 \\
\hline Di Yogyakats & 486.306 .319 .893 & 386.152 .992 .682 \\
\hline Jawa Timur & 73.381.554.834 & 3.610 .572 .473 .701 \\
\hline Banten & 760.997.185.126 & 1.224 .786 .923 .461 \\
\hline Bali & $135.273,309.976$ & 730.106 .078 .763 \\
\hline Nusa Tenggara Bsral & 144.426 .264 .056 & 278.767 .423 .792 \\
\hline Nusa Tenggara Timur & 173.057.248.380 & 190.827 .688 .158 \\
\hline Kalimantan Barat & 721.617.879.858 & 405.404 .968 .564 \\
\hline Kalimantan Tengah & 114.176.825.644 & 313.428.192.398 \\
\hline Kalimantan Selatar & 71.198.759.489 & 724.678.071.241 \\
\hline Kalimanten Timur & 24.022 .171 .499 & 1.665 .780 .205 .302 \\
\hline Kalimantan Utara & 64.558 .232 .571 & 29.585 .008 .077 \\
\hline Sulawesi Utara & 224.114.881.952 & 234.421 .603 .792 \\
\hline Sulawesi Tengah & 31.051 .432 .939 & 206.154.203.184 \\
\hline Sulamesi Selazan & 61.346.662.077 & 757.284 .543 .851 \\
\hline Sulawesi Tenggara & 138.130 .142 .153 & 149.986 .872 .864 \\
\hline Gorontalo & 78.553 .863 .181 & 70.480 .598 .912 \\
\hline Sulawesi Barat & 68.256 .133 .324 & 55.659 .482 .045 \\
\hline Maluku & 65.205 .426 .907 & 106.357 .219 .888 \\
\hline Maluku L & 50.992 .412 .326 & 50.765 .465 .334 \\
\hline Papua Barat & 255.968 .711 .949 & 76.669 .132 .677 \\
\hline Papua & 191.072 .264 .083 & 236.234 .003 .493 \\
\hline Agreg & 17.971 .260 .826 .270 & 30.393 .136 .894 .593 \\
\hline
\end{tabular}

Source: Data Processed 2017.
RJOAS, 3(75), March 2018

Table 2 - DBH Allocation after Reformulation of 2015 (in Rp.)

\begin{tabular}{|c|c|c|}
\hline \multirow{2}{*}{ Province } & \multicolumn{2}{|c|}{2015} \\
\hline & Pre & Post \\
\hline Aceh & 247.001 .807 .000 & 493.014.668.457 \\
\hline Sumatera Utara & 430.178 .194 .000 & 1.220 .976 .704 .142 \\
\hline Sumblera Barat & 123.593 .339 .000 & 469.185 .685 .312 \\
\hline Riau & 983.884 .146 .000 & 869.242 .987 .681 \\
\hline Jambi & 250.573 .279 .000 & 310.307 .344 .686 \\
\hline Sumalera Selitan & 251.648 .070 .000 & 633.635 .431 .125 \\
\hline Bengkulu & 735.550 .727 .000 & 175.326 .004 .950 \\
\hline Lampung & 52.979 .709 .000 & 561.839 .519 .125 \\
\hline Kep. Bangka Belitung & 48.635 .402 .000 & 142.951 .353 .860 \\
\hline Kep. Risu & 140.030 .974 .000 & 253.307.491.632 \\
\hline DKa Jakarta & 11.137 .137 .741 .000 & 8.421 .548 .850 .397 \\
\hline Jawa Barat & 1.222 .867 .463 .000 & 4.008 .235 .933 .155 \\
\hline Jawa Tengah & 477.971 .597 .000 & 2.726 .222 .463 .286 \\
\hline DI Yogyakata & 562.677 .524 .000 & 398.279 .438 .065 \\
\hline Jawa Timut & 88.891 .974 .000 & 3.850 .680 .259 .973 \\
\hline Banten & 889.745 .339 .000 & 1.243 .189 .912 .806 \\
\hline Bati & 146.371 .666 .000 & 760.326 .514 .237 \\
\hline Nusa Tenggara Barat & 162.557 .373 .000 & 343.167.713.701 \\
\hline Nusa Tenggara Timur & 191.604 .578 .000 & 220.581 .326 .934 \\
\hline Kalimantan Barat & 796.833 .654 .000 & 425.637 .827 .614 \\
\hline Kalimantan Tengah & 108.341 .438 .000 & 293.743 .478 .339 \\
\hline Kalimantan Selatan & 80.720 .820 .000 & 671.228 .911 .030 \\
\hline Kalimantan Timur & 25.912 .346 .000 & 1.237 .542 .032 .472 \\
\hline Kalimantan Utara & 72.066 .087 .000 & 92.511 .916 .845 \\
\hline Sulamesi Utara & 215.217 .353 .000 & 253.237 .615 .988 \\
\hline Sulawesi Tengah & 31.288 .379 .000 & 226.235 .649 .685 \\
\hline Sulawesi Selzan & 62.901 .682 .000 & 817.711 .122 .562 \\
\hline Sulawesi Tenggara & 157.066 .506 .000 & 166.770 .993 .074 \\
\hline Gorontalo & 83.285 .625 .000 & 72.389 .836 .241 \\
\hline Sulawesi Barat & 79.735 .761 .000 & 68.377 .417 .423 \\
\hline Maluku & 64.766 .758 .000 & 97.704 .164 .625 \\
\hline Maluku Utara & 64.275 .409 .000 & 59.014.114.698 \\
\hline Papua Barat & 289.457 .583 .000 & 80.700 .282 .734 \\
\hline Papua & 249.473 .710 .000 & 228.228 .664 .947 \\
\hline Agregat & 20.525 .244 .013 .000 & 31.893 .053 .631 .801 \\
\hline
\end{tabular}

Table 3 - DBH Allocation after the Reformulation of 2016 (in Rp.)

\begin{tabular}{|c|c|c|}
\hline \multirow{2}{*}{ Province } & \multicolumn{2}{|c|}{2016} \\
\hline & PRE & POST \\
\hline Aoeh & 165.964.037.278 & 508.001 .268 .200 \\
\hline Sumatera Utara & 396.953 .644 .620 & 1.238 .714 .814 .526 \\
\hline Sumatera Barat & 106.809.651.027 & 491.039 .653 .419 \\
\hline Risu & 753.011.357.350 & 777.666 .987 .168 \\
\hline Jambi & 88.019 .169 .067 & 308.380 .249 .975 \\
\hline Sumatera Selatan & 171.339 .035 .792 & 636.548 .210 .998 \\
\hline Bengkulu & 572.194.707.779 & 182.890.093.159 \\
\hline Lampung & 45.452 .388 .896 & 592.202 .922 .072 \\
\hline Kep. Bangka Belitung & 39.221 .088 .709 & 143.565 .243 .102 \\
\hline Kep. Riau & 118.542 .210 .584 & 269.828 .347 .566 \\
\hline DKI Jakarta & 11.850 .246 .587 .258 & 9.222 .009 .046 .490 \\
\hline Jawa Barat & 1.254 .900 .933 .191 & 4.260.745.550.829 \\
\hline Jawa Tengah & 507.766 .983 .540 & 2.885 .273 .438 .072 \\
\hline Dl Yogyakanta & 574.798.422.726 & 418.439 .045 .385 \\
\hline Jawa Timur & 86.718 .849 .679 & 3.954.467.072.807 \\
\hline Banten & 859.468 .926 .540 & 1.365 .794 .685 .771 \\
\hline Ball & 122.975.577.435 & 760.300 .715 .327 \\
\hline Nusa Tenggara Barat & 137.186 .495 .789 & 339.963.323.951 \\
\hline Nusa Tenggara Timur & 155.606.923.823 & 248.799.045.196 \\
\hline Kalimantan Barat & 625.645 .249 .816 & 416.086 .985 .357 \\
\hline Kalimantan Tengah & 75.076 .441 .150 & 289.577 .141 .783 \\
\hline Kalimantan Selatan & 82.133 .475 .258 & 625.020 .245 .853 \\
\hline Kalimantan Timur & 16.687 .888 .649 & 1.007 .343 .090 .191 \\
\hline Kalimantan Utara & 56.663 .362 .810 & 126.989.182.618 \\
\hline Sulawesi Utara & 184.066.815.501 & 245.262 .262 .519 \\
\hline Sulawesi Tengah & 20.090 .882 .896 & 234.774 .387 .054 \\
\hline Sulawesi Selatan & 49.754 .885 .686 & 862.394 .309 .535 \\
\hline Sulawesi Tenggara & 154.215.298.447 & 186.188 .687 .426 \\
\hline Gorantalo & 78.287 .823 .809 & 77.806.348.551 \\
\hline Sulawesi Barat & 60.690 .412 .906 & 69.422 .138 .149 \\
\hline Maluku & 48.691 .247 .502 & 116.552 .871 .920 \\
\hline Maluku Utara & 43.755 .414 .090 & 70.038 .067 .682 \\
\hline Papua Barat & 251.325 .818 .344 & 84.703 .235 .254 \\
\hline Papua & 157.682 .484 .745 & 254.934 .818 .033 \\
\hline Agregat & 19.911.944.492.691 & 33.271 .723 .485 .940 \\
\hline
\end{tabular}


RJOAS, 3(75), March 2018

Table 4 - Change of Coefficient Vertical Imbalance (CVI) DBH Reformulation of 2014-2016

\begin{tabular}{|c|c|c|c|c|c|c|}
\hline & \multicolumn{2}{|c|}{2014} & \multicolumn{2}{c|}{2015} & Post & Pre \\
\hline $\mathrm{CVI}_{1}$ & Pre & Post & Pre & 0,4016 & 0,097 \\
\hline $\mathrm{CVI}_{2}$ & 0,119 & 0,518 & 0,110 & 0,424 & 0,414 \\
\hline $\mathrm{CVI}_{3}$ & 0,120 & 0,519 & 0,111 & 0,424 & 0,100 \\
\hline
\end{tabular}

Source: Data Processed 2017.

Figure 1 - Change of Coefficient Vertical Imbalance (CVI) After Aggregate of Tax and Natural Resources Reformulation of 2014-2016

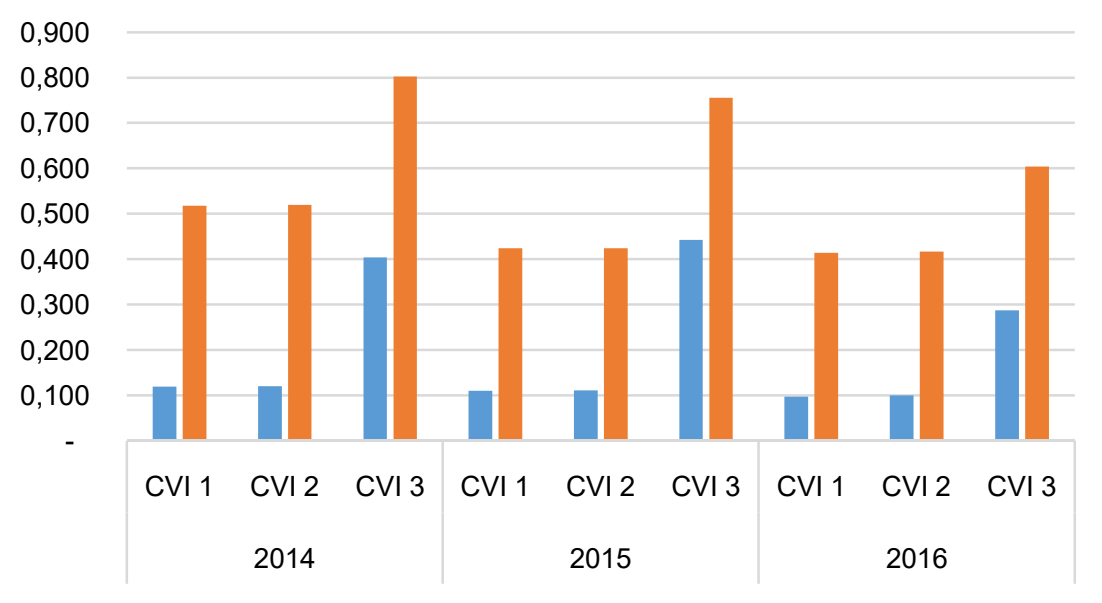

Source: Data Processed 2017.

Based on table 4 and figure 1 shows that the simulation results of allocation of FundBased Funds transfers based on DBH reformulation have a positive effect on the change of vertical fiscal inequality coefficient. Overall both CVI1 CVI2, and CVI3 indicate an increase in coefficient numbers.

In conclusion, the values of CVI1 CVI2, as well as CVI3 have increased. This means that the operationalization of DBH reformulation is relatively good and has a positive effect. This can be demonstrated by the result of increasing DBH reformulation. The DBH Reformulation encourages increased transfers to the regions so as to increase the fiscal capacity of the regions.

\section{CONCLUSION}

The result of $\mathrm{DBH}$ reformulation shows that vertical fiscal imbalance is decreasing. This is demonstrated by the CVI ratio before and after the $\mathrm{DBH}$ reformulation, in which $\mathrm{CVI}$ after $\mathrm{DBH}$ reformulation becomes better. In line with that, the $\mathrm{DBH}$ reformulation is able to increase the fiscal capacity of the regions, as indicated by the increase of $\mathrm{DBH}$ allocation after the $\mathrm{DBH}$ reformulation simulation.

\section{REFERENCES}

1. Ananda, Candra Fajri. 2002. Problems Of The Implementation Of Fiscal Decentralization In Regional Autonomy: The Case Of Malang Municipality And Trenggalek District. Center for Institutional Reform and the Informal Sector (IRIS) University of Maryland at College Park. http://pdf.usaid.gov/pdf_docs/PNACR397.pdf. Accessed on, November 30 ${ }^{\text {th }}, 2017$

2. Bird, R. M., \& Tarasov, A. V. (2004). Closing the gap: Fiscal imbalances and intergovernmental transfers in developed federations. Environment and Planning $\mathrm{C}$ : Government and Policy, 22(1), 77-102. https://doi.org/10.1068/c0328

3. Bird, R., \& Vaillancourt, F. (2000). Fiscal Decentralization in Developing Countries: An Overview and Perspective, paper presented at The International Seminar in Public 
Economics. Tokyo. Japan.

4. Hamid, E. S. (2005). Formula Alternatif Dana Alokasi Umum (DAU): Upaya Mengatasi Ketimpangan Fiskal dalam Era Otonomi Daerah. Yogyakarta, UII Press.

5. Kenworthy, L., \& McCall, L. (2008). Inequality, public opinion and redistribution. SocioEconomic Review (2008), 6, 35-68.

6. Khusaini. (2014). Local government planning and budgeting process : a case of districts and cities in Indonesia Mohamad Khusaini, 7(2), 6-8.

7. Khusaini. (2017). IJEM Local Taxes and Pro-cyclical Fiscal Policy in Indonesia, 11, 261269.

8. Khusaini, M. (2008). Kajian Desentralisasi Fiskal, Dampaknya Terhadap Efisiensi Ekonomi Sektor Publik, Pertumbuhan Ekonomi Daerah Dan Kesejahteraan Masyarakat (Studi Pada Kabupaten/Kota Di Jawa Timur). Jurnal-Jurnal Ilmu Sossial (Social Science)., Volume 20.

9. Khusaini, M. (2016). The role of public sector expenditure on local economic development. International Journal of Economic Policy in Emerging Economies, 9(2), 182. https://doi.org/10.1504/IJEPEE.2016.077279

10. Shah, A., \& Qureshi, Z. (1994). Intergovernmental Fiscal Relations in Indonesia (Word Bank Discussion paper No. 239). 